\title{
ウェアラブル健康管理パッチデバイスの開発に向けて
}

\author{
竹井 邦晴*
}

\section{Toward Flexible and Wearable Health Monitoring Patch Devices}

Kuniharu TAKEI*

* 大阪府立大学 ( $\bar{T}$ 599-8531 大阪府堺市中区学園町 1-1)

* Osaka Prefecture University (1-1 Gakuen-cho, Naka-ku, Sakai, Osaka 599-8531)

\section{1. はじめに}

本解説の読者の皆様は, 現在生活おいて心配事はありま すか？ 本質問にはさまざまな回答があるかと思います。 最新の世論調査では, 生活における心配事の 1 位に「お 金」, 続いて 2 位に「自分の健康」, 3 位に「家族の健康」と なっています。またこれは日本のみに限らず世界的な傾向 であることがわかっています。しかしながら健康に関する 興味が高いのに対し, 健康診断や人間ドックの受診率は $68 \%$ 程度といわれている。未受診の理由は, 時間がない, 費用がかかる，面倒だからといったものである。ここで 「健康」について着目した理由は, 図 1 に示すように, 「健 康」と「幸福」には強い相関関係があることがわかってお り, 今後さらなる発展に向け「健康」および「幸福度の高 い」社会構築が重要課題であるためである。これは, より 良い「健康」を維持することで高い「幸福」度を得ること ができ, 結果として「ストレスの少ない生活」が実現でき る。このストレスの少ない生活が「活気あふれる社会」を 実現し, さらに高い「幸福」度が得られる。この正のサイ クルを維持することで, 人々の生活の向上が見达める。こ れにより幸福度が高く, 活気あふれる魅力的な社会構築が 可能となり, このような生活・社会の実現が今後のわれわ

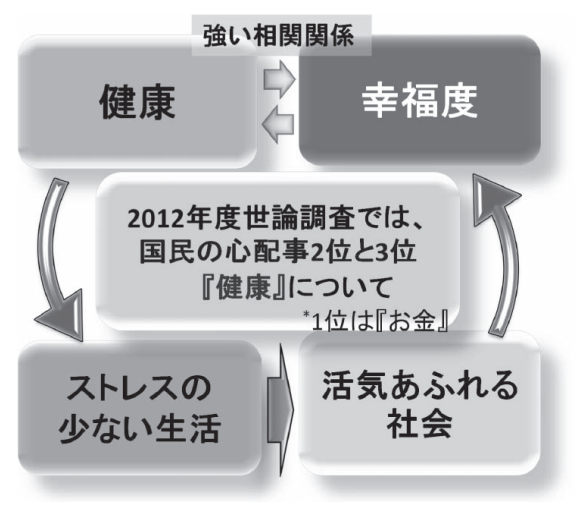

図 1. 健康と幸福度および活気あふれる社会構築の相関関 係
れの生活には重要且つ必要不可欠になることは間違いない。

繰り返しになるが，人々の健康を維持することで快適な 社会の実現が期待できる。しかし現在，高齢化社会さらに は超高齢化社会と言われるほど高寿命化が進んでおり，健 康の維持には医療費, 病院数, 医師・看護師の負担が今後 益々増加すると予想されている。またこのような負担の軽 減に向け健康診断の受診率を上げることで病気を未然に防 ぐ努力も必要である。

そこでこれらの問題を解決する一つの可能性として，わ れわれのグループでは䋖創膏または衣服のようなフレキシ ブルな基板上に電子デバイスを作製することで実現する ウェアラブルデバイスの開発に取り組んでいる ${ }^{1), 2)}$ 。れ は，ウェアラブルデバイスをフレキシブル化することで装 着感や違和感無く体から健康状態をリアルタイム計測する ことを目指している。またデバイスを印刷技術などで知ら れる大面積且つ低価格化プロセスで作製することで，デバ イス単価を下げ，より多くの人に利用してもらえるウェア ラブル・フレキシブルデバイス実現を行う。本実現によ り, 現在商品化されているウェアラブルデバイスの高価格 による低普及率および硬いデバイスによる装着感・違和感 などから困難であったさまざまな条件下（例えば睡眠時な ど）やさまざまな人からの健康状態のリアルタイム計測を 可能にする。これにより得られた結果を蓄積・解析するこ とで将来的には予防医療などの応用へと発展することも期 待できる。また健康状態のリアルタイム管理により通院費 の削減や医師・看護師の負担軽減, さらには孤独死などの 問題解決にも適用が期待できる。本研究では，皮膚に直接 触れるデバイスのため衛生面を考慮し, 一般的な絆創膏の ような使い捨てデバイスを基礎とすることを提案してい る。特に印刷形成によりセンサの低価格が期待できるため 図 2 に示すように使い捨てセンサシートとする。本ウェア ラブル健康管理デバイス実現には，センサのみではなく信 号処理回路などプロセスが複雑なデバイスの集積化も必要 不可欠である。しかし本デバイスを使い捨てデバイスとす ることは価格面で困難である。そこで本研究では複雑なプ 

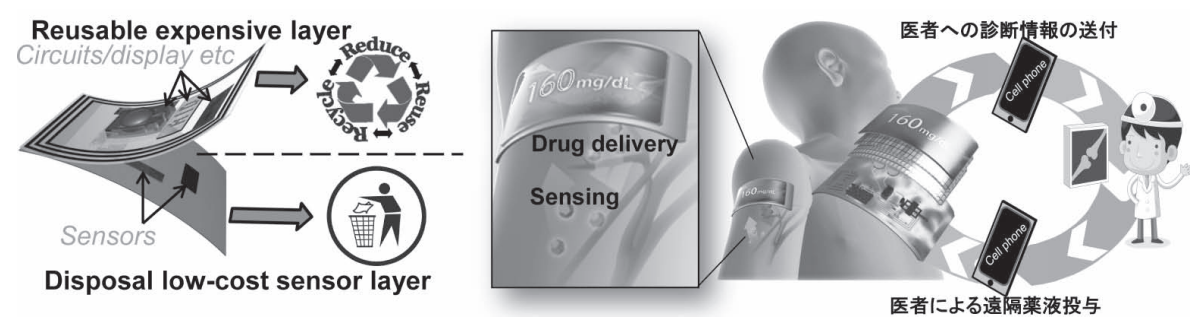

図 2. 本研究が目指すウェアラブル・フレキシブル健康管理デバイス。使い捨てセン サシートと再利用デバイスシートで構築。無線機能なども搭載することで遠隔 による医師の診断なども可能にする

ロセスを必要とするデバイスは再利用デバイスシートと し，使い捨てセンサシートと再利用デバイスシートの取り 外しを可能にすることで衛生面と可能な限りの低価格化を 実現する ${ }^{3)}$ 。また図 2 に示すように薬液搬送デバイスや無 線デバイスも同時に集積化することで緊急時の自動薬液投 与や遠隔からの医師による常時健康状態の管理を可能にす る。本解説では, 著者がこれまで行ってきた印刷技術によ り形成した使い捨て可能なフレキシブルセンサについて紹 介する。ただし残念ながら図 2 に示すようなウェアラブル デバイス実現には, さらなる研究開発が必要であり, 本解 説では本実現へ向けた各センサについてのみ紹介する。

\section{2. 印刷形成による大面積フレキシブルデバイス}

\section{1 歪み, 温度センサ}

ウェアラブル健康管理デバイス実現へ向け，さまざまな センサが必要になる。その中でも, 本解説では活動量セン サ (加速度センサ), 心拍計測センサ, 皮膚表面温度計測に 応用が可能な歪みセンサおよび温度センサについて紹介す る 2),4) 6)。上述したように本研究では, 使い捨てセンサシー 卜を目指しており, 低価格で大面積デバイス形成が可能な 印刷技術によるセンサ形成方法の開発に注目する。

まず歪みセンサは, 銀 $(\mathrm{Ag})$ ナノ粒子 (NP) インク（韓国 Paru 社製) および単層カーボンナノチューブ (CNT) インク (米国 SWeNT 社製) を混ぜることでスクリーン印刷形成可

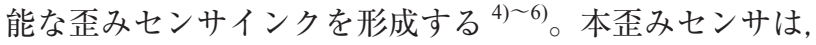
歪みが印加されると AgNP 間の距離が変化する。結果とし て電気抵抗が変化し, この抵抗変化量から歪み量を算出す ることができる。CNTは, 強い引っ張り応力が印可された 場合，AgNP 間を電気的に接続する役割であり，これによ り高いダイナミックレンジを実現している。AgNPインク およびCNTインクの合成比を変えることで歪みセンサの感 度を容易に調整することが可能であり, 最大感度は AgNP と CNT インクの混合質量比 4:5 で〜 59\%/Pa（ただし，フィ ルム長 $8 \mathrm{~mm}$, 膜厚 $0.5 \mathrm{~mm}$ のシリコーンラバー上での結果) を得ることが可能である。ここでは, AgNP と CNT インク の混合比 3:5 を用いて歪みセンサを作製した。インクのス クリーン印刷後, $70^{\circ} \mathrm{C}$ で約 1 時間焼成した。さらに必要に 応じて Ag 電極を市販されているインク（アサヒ化学研究

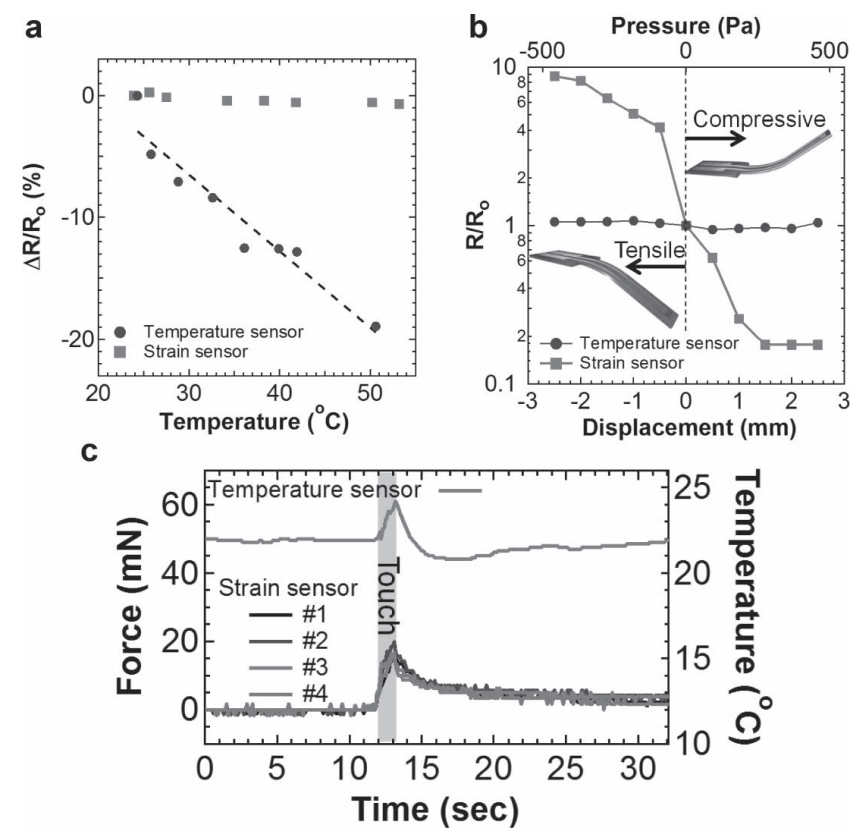

図 3. 印刷形成した温度センサおよび歪みセンサの (a) 温 度変化に対する抵抗変化率, および (b) 曲げもしく は印加圧力に対する抵抗変化の結果。(c) 指の触覚に よる温度センサと歪みセンサの応答特性 ${ }^{4), 5)}$ 。

所製）を用いてスクリーン印刷することで歪みセンサを作 製した。

温度センサ用インクは, 歪みセンサと同様の CNT インク と導電性高分子である poly (3,4-ethylenedioxythiophene) polystyrene sulfonate (PEDOT: PSS)（米国 Sigma Aldrich 社

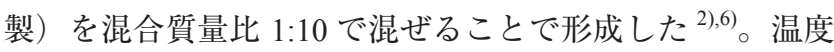
センサの原理は, 明確にはわかっていないが CNT と PEDOT:PSS 界面での温度変化における電子のホッピング伝 導確率の変化によるものであると考えられる。そのため本 温度センサも歪みセンサ同様に抵抗変化型のセンサであ る。印刷後, $70^{\circ} \mathrm{C}$ で約 1 時間焼成した。電極は, 歪みセン サ同様 Ag 電極を印刷することで形成した。

最初に歪みセンサおよび温度センサの温度および基板の 曲げ（歪み）に対する各センサの特性について示す。図 3a には両センサの温度に対する抵抗の変化率の結果を示す。 本デバイスはウェアラブルデバイスへの応用を目指してい 
るため, 測定温度は室温から $50^{\circ} \mathrm{C}$ 程度までとした。結果 から温度センサは温度に対して直線的に抵抗が減少するの に対して, 歪みセンサは温度に対してほぼ変化しないこと が明らかになった。温度センサの温度による抵抗変化率か ら算出した感度は, 約 $0.63 \% /{ }^{\circ} \mathrm{C}$ であった。それに対して 歪みセンサは温度に対して約 $0.03 \% /{ }^{\circ} \mathrm{C}$ の感度であった。 次に歪みに対する両センサの抵抗変化率の結果を図 $3 b$ に示 す。歪みセンサは印加圧力（基板の曲げ）に応じて抵抗が 大きく変化し，その圧力に対する抵抗変化率から算出した 感度は，2\%/Paであった。繰り返しになるが図 $3 a$ に示す歪 みセンサは AgNP と CNT インクの混合比 3:5 を用いている ため, 上述の最高感度とは異なることを注記しておく。そ れに対し温度センサは基板の曲げに対し約 $0.02 \% / \mathrm{Pa}$ 程度 の変化であった。このように温度センサは温度に対し, 歪 みセンサは歪み量に対してのみ高い検出感度を有してお り, 両センサを集積化しても高い選択性を有した信号検出 が可能であることが確認できた。最後に歪みセンサおよび 温度センサを人の指で触ることによるセンサ出力のリアル タイム計測を行った。歪みセンサは 4 個同時に計測を行っ た。図 $3 \mathrm{c}$ に示すように温度抢よび歪みセンサ共に人の触覚 に対して反応しているのを確認した。

\section{2 多機能化を目指した絆創膏型デバイス}

ウェアラブルデバイスとしての可能性を示すため, 最初 のプロトタイプとして印刷技術のみによる触覚センサ, 温 度センサ, 無線コイル, そして薬液搬送用フレキシブルポ ンプをカプトン基板上に集積化した（図 4a-b) 2)。フレキシ ブルポンプは, 半球状に形成した空洞内に薬液 (本実験で は赤色に染めた水）を充填し, その部分に圧力を加えるこ とでマイクロ流路を介して, カプトン基板下側（皮虐に触 れる側）から薬液が排出される仕組みである。フレキシブ ルポンプは, ポリマー材料である Polydimethylsiloxane (PDMS) を型形成することで作製しており，ゴムのような 柔軟性を有しているためフレキシブルデバイスとしての活 用が可能である。図 $4 \mathrm{c}$ には, 薬液排出口にガーゼを配置し た場合の薬液排出前後に扔けるデバイスの写真を示す。写 真の色のコントラストからもわかるように, PDMS ポンプ に圧力を印加することで薬液を排出することが可能である ことが確認できた。次に, 無線コイルと容量型の触覚セン
サを直列接続することで無線による触覚の検出および温度 検出を行った。実験は人の指で作製したデバイスに触るこ とによる触覚センサと温度センサの変化をリアルタイム測 定した。無線コイルの共振周波数 $42 \mathrm{MHz}$ を用いて触覚の 検出を行った。図 $4 \mathrm{~d} に$ 示すように，指の触覚による温度変 化掞よび無線での触覚の検出が可能であることが確認でき た。最後に本デバイスを腕に装着し, 活動時における皮䖉 表面温度の変化の計測を行った。本害験では，辛いスープ の飲食時㧍よび室内での運動時における皮虐表面温度の変 化の観測を行った。本デバイスを腕に装着すると, 図 5 の ように正常時の皮膚表面温度である約 $29-31^{\circ} \mathrm{C}$ に温度は上 昇し，さらに辛いスープの飲食時には発汗作用によるもの と考えられる原因で皮膚表面温度は $32.5^{\circ} \mathrm{C}$ 程度まで上昇 し, そして正常時皮虐表面温度へと隇少する傾向が得られ た。それに対して室内に扔ける運動中は正常時と比較し温

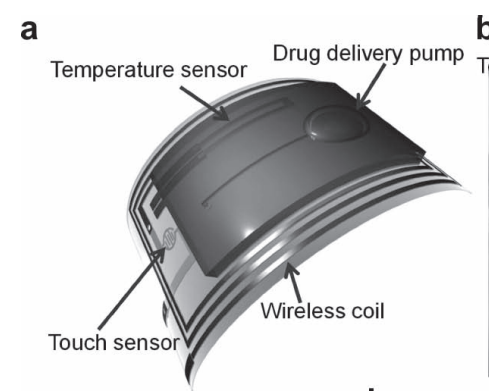

b Drug delivery pump

C

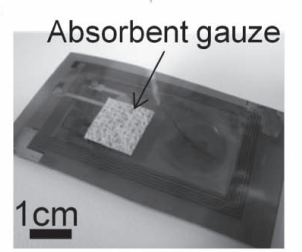

d 0
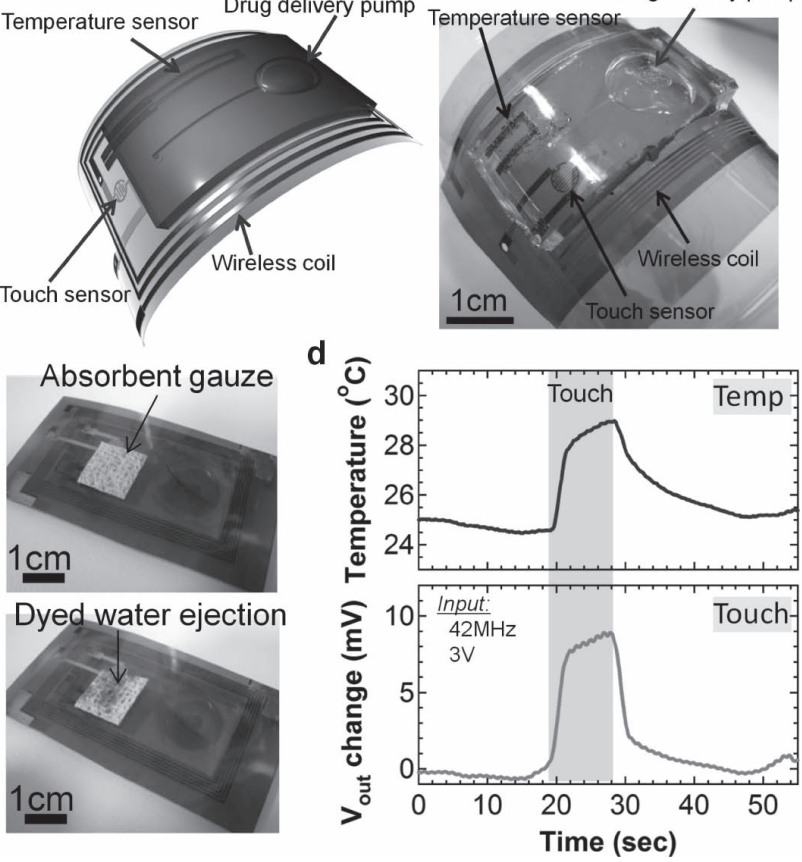

図 4. 本研究で提案する紏創膏型健康管理デバイスの (a) イ メージ図および (b) 作製したデバイス写真。(c) 薬液 搬送前後のデバイス写真。(d) 指の触覚による温度セ ンサおよび無線検出による触覚センサのリアルタイ 厶計測結果 ${ }^{2)}$ 。

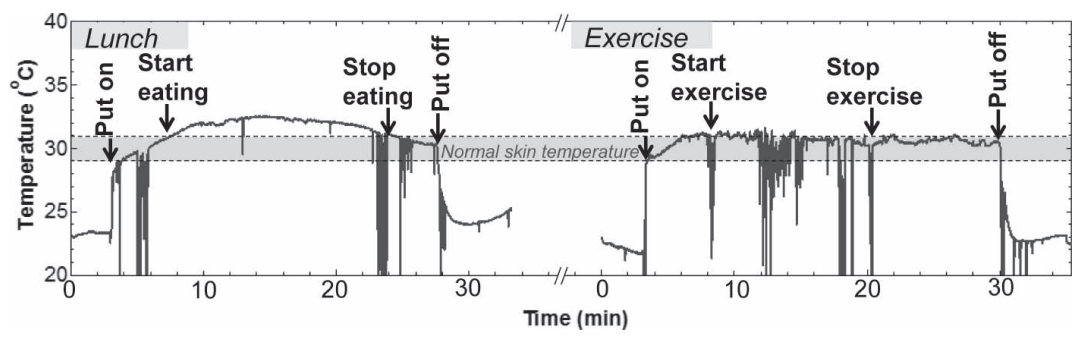

図 5. 印刷形成した温度センサによる, 辛いスープの飲食時および軽い運動 時の皮膚表面温度の計測結果 ${ }^{2}$ 。 
度変化がほとんど得られなかった。本理由としては室内に 扔ける軽い運動且つ短い（12 分程度）運動であり, 運動終 了時に直ちにデバイスを外してしまったため発汗作用など の影響が観察できなかったものであると考えられる。本研 究ではウェアラブルデバイスの開発に焦点を当てているた め, 活動時における皮膚表面温度のさらなる解析などは 行っていない。最後に, 図 4 で示したデバイスには歪みセ ンサの集積は行わなかったが, 別で作製した歪みセンサを 手首に添付することで, 図 6 のように脈拍を計測すること も可能である。

本解説で示した歪みセンサおよび温度センサは一例であ り, 今後さらなる発展によりさまざまな応用デバイスが期 待できる。このように印刷技術で形成したセンサでも，材 料の最適化などを行うことでさまざまな応用（本研究では 健康状態の検出）に適用可能であることを示し, さらに低 価格・大面積フレキシブルセンサの可能性を示唆すること ができた。
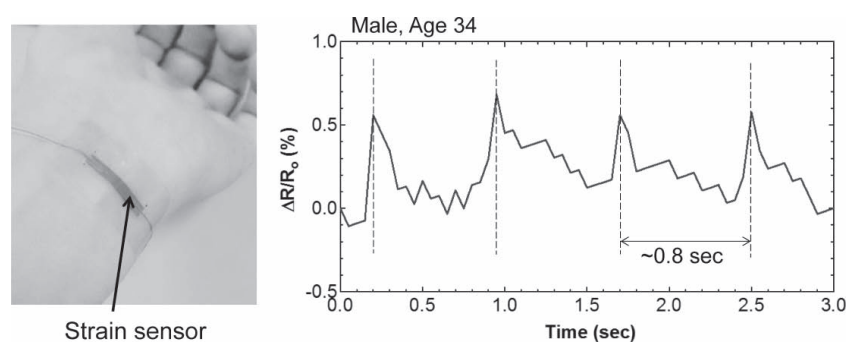

図 6. 印刷形成した歪みセンサによる脈拍計測結果

\section{3 使い捨て, 再利用デバイスシート間電気接続}

本研究で提案する使い捨てシートと再利用シートデバイ スを実現するには基板のフレキシブル性を維持した状態で シート間の電気接続を行うのが理想である。そこで本研究 では，安定且つフレキシブル性を実現する方法として液体 金属である共晶ガリウムーインジウム (EGaIn) の利用を提 案する ${ }^{3)}$ 。予備実験として液体金属を用いた EGaIn と印刷 形成した $\mathrm{Ag}$ 電極間の曲げによる電気抵抗の安定性などの 解析を行った。構造は, 再利用シート側に EGaIn を保持す る小さいチャンバーをPDMS で作製し，Ag 電極を形成し たポリエチレン (PE) 基板と一体化させる（図 7a）。使い捨 てシート (sheet 2) には低価格化を実現するため電極および センサのみとする。ただし本実験では電極のみでありセン サは形成していない。実際に作製した再利用シートおよび 使い捨てシートを図 7bに示す。図 7c には, EGaIn-Ag 電極 接触時の基板の曲げ（曲率半径 $6.3 \mathrm{~cm}$ ）時の抵抗変化率 を示している。また比較のため液体金属を用いない場合の $\mathrm{Ag}-\mathrm{Ag}$ 電極接触のサンプルも同様の実験を行った。なお接 触抵抗は EGaIn-Ag および $\mathrm{Ag}-\mathrm{Ag}$ 接触共に $1 \Omega$ 以下である ことを確認している。結果から明らかなように $\mathrm{Ag}-\mathrm{Ag}$ 電極 接触では曲げ時に $10 \%$ 以上抵抗が変化してしまうのに対し て, EGaIn-Ag 電極接触では，ほほ抵抗が変化せず安定した 電気接触が実現できているのがわかる。また図 $7 \mathrm{~d} に$ 示すよ うに, EGaIn-Ag 電極接触では曲率半径 $2 \mathrm{~cm}$ 程度の曲げで あっても抵抗の変化がほぼ無視できるのに対して, Ag- Ag 電極接触では曲率半径 $6 \mathrm{~cm}$ 以下の曲げで電気的接触を保持

a

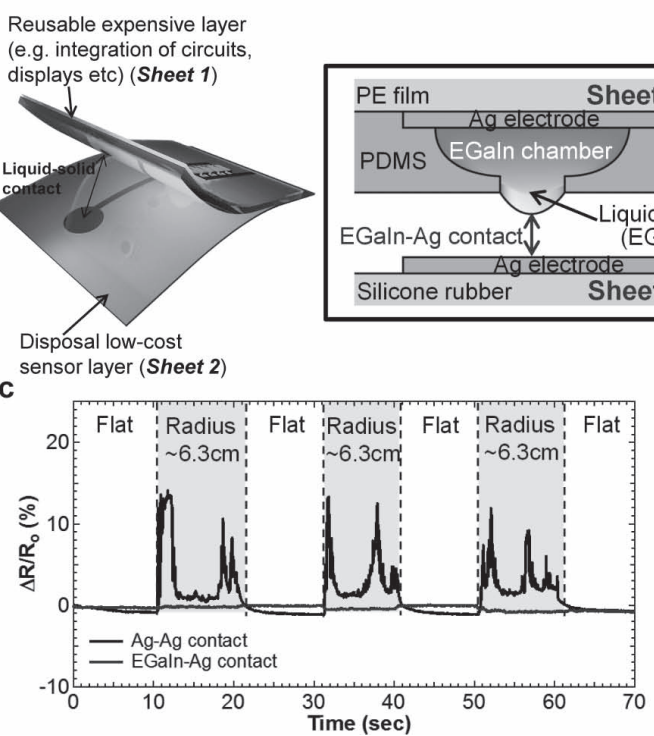

b

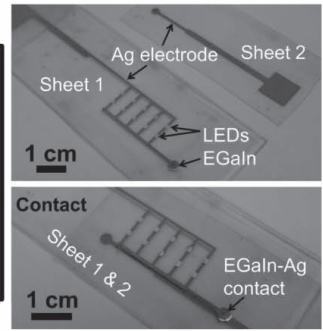

d

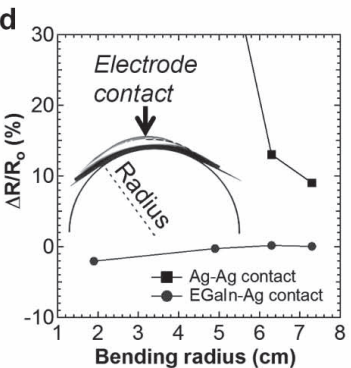

図 7. (a) 液体金属 EGaln を用いた再利用デバイスシート (Sheet 1) と使い捨 てセンサシート (Sheet 2) 間の電気接触のイメージ図。(b) プロトタイ プとして作製したデバイス写真。(c) 基板の曲げ（曲率半径 $6.3 \mathrm{~cm}$ ) に よる液体金属 EGaln と Ag 電極の接触抵抗。同時に $\mathrm{Ag}$ 電極と $\mathrm{Ag}$ 電極 を用いた際の接触抵抗も示す。(d) 基板の曲げによる EGaln-Ag 電極接 触と $\mathrm{Ag}-\mathrm{Ag}$ 電極接触の抵抗変化率。 $\mathrm{Ag}-\mathrm{Ag}$ 電極は, 曲率半径 $6 \mathrm{~cm}$ 以 下ではオープン回路になり抵抗の測定が不能 ${ }^{3)}$ 。 


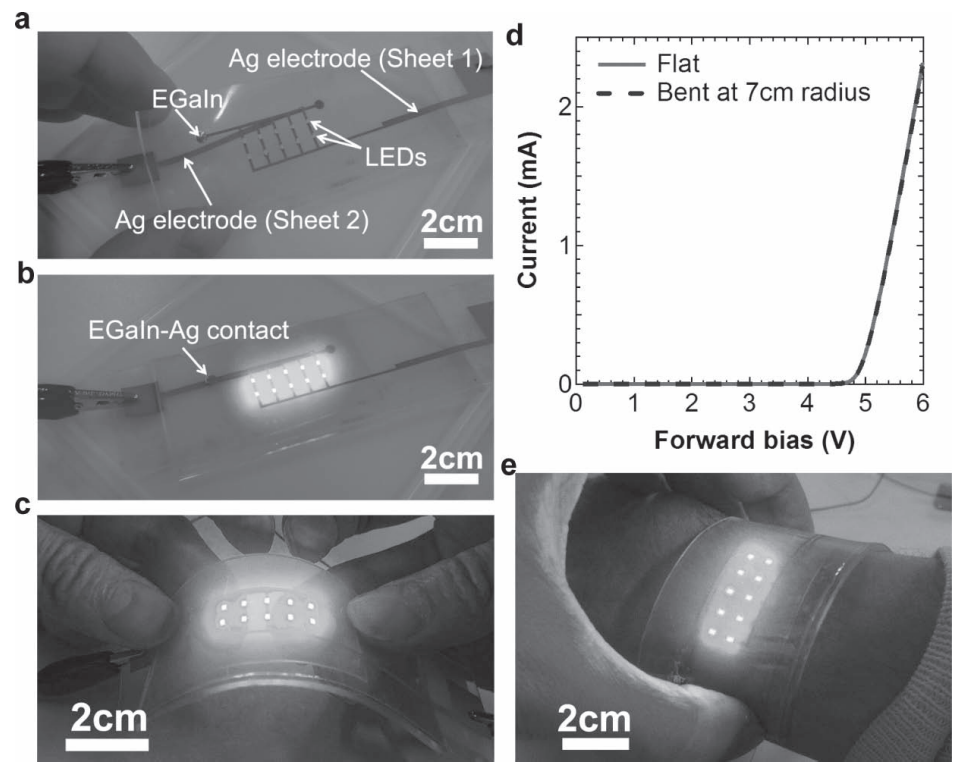

図 8. 再利用シート（チップLED の集積）と使い捨てシートのデ モンストレーション。(a) EGaln-Ag 電極接触前 (LED OFF),

(b) EGaln-Ag 電極接触後 (LED ON), (c) 基板の曲げに対して も LED がオンであることを確認。(d) 基板曲げ（曲率半径 7 $\mathrm{cm})$ における電流一電圧特性の結果。(e) 腕に巻き付けた場 合のデバイス写真 ${ }^{3)}$ 。

することができないことが実験的に確認できた。また結果 は示していないが, 1,000 回以上の接触においても安定した 低抵抗を維持し，また $\mathrm{Ga}$ の酸化による抵抗の上昇などの 影響もほぼ無いことを確認している3)。

最後に簡単なデモンストレーションとして, チップ LED を再利用フレキシブル基板上に実装し, EGaIn-Ag 電極の接 触安定性を示す。図 8 のように使い捨てシートと再利用 シート（LED 実装基板）を接触させると LED がオンにな り，曲げても LED の特性が安定であることが確認できた。 これは上述した図 7 の結果とも良く一致しており, 安定し たフレキシブルデバイス実現へ向けた一つ可能性を示唆す ることができた。

\section{3. むすび}

本解説では，われわれが現在取り組んでいる印刷技術に よるフレキシブルセンサシートについて， ウェアラブル • フレキシブル健康管理デバイスに着目し紹介してきた。こ こで紹介した技術に加え, 現在われわれはフレキシブル活 動量センサ，心電センサなどの開発も同時に行っている。 またフレキシブルデバイス実現には, 低消費電力のフレキ シブル信号処理回路や増幅回路などの集積化技術が必要に なってくる。そこで無機ナノ材料を主に用いたフレキシブ ル CMOS (Complementary Metal-Oxide-Semiconductor) 回路の 開発も行っている7)。しかしながら 1 グループが研究開発 出来る範囲には限界があり, さまざまな分野の研究者の協 力を必要としているのが現状である。現在, このフレキシ ブル回路やセンサ，さらには実用化へ向けた取り組みが国
内外で盛んに行われている。特に著者が知る限り日本 ${ }^{8)}$ 10) だけでなくアメリカ ${ }^{11)}$, 韓国 ${ }^{12)}$, 中国 ${ }^{13)}$ が本研究開発を 積極に行っている印象がある。このフレキシブルデバイス は，次世代デバイスとしてブレイクスルーを起こす電子デ バイスの一つであることが期待できる点などを考慮する と, 日本も益々本分野への研究開発を加速させる必要があ る。特に有機材料，無機材料の融合による高性能・低消費 電力・多機能フレキシブルデバイスが実用化に向けた今後 の焦点になると考えられる。またデバイス作製のみではな く，本フレキシブルデバイスの実用化へ向けた実装技術の 開発も必要不可欠である。最後に，本フレキシブルデバイ ス分野で日本が世界をリードできるよう産学官連携による 本分野の活性化および研究開発の加速をお願いし本解説の 結びとさせていただきます。

\section{謝 辞}

本研究は, 日本学術振興会 (JSPS) 科学研究費助成事業若 手研究 (A)（課題番号 26709026), 挑戦的萌芽研究（課題番 号 26630164), 立石科学技術振興財団研究助成, 国際科学 技術財団研究助成, マツダ財団研究助成, ATI 研究助成な ど多くの支援を受けて行われた結果である。本稿の内容は 大阪府立大学の秋田成司教授, 有江隆之准教授, 学生の本 田 航氏, 原田真吾氏, 金尾顕一朗氏, 山本祐輝氏との共 同研究で行われたものです。この場を借りて御礼申し上げ ます。

(2015.7.1- 受理) 


\section{文献}

1) K. Takei, W. Honda, S. Harada, T. Arie, and S. Akita: "Toward Flexible and Wearable Human-Interactive Health-Monitoring Devices,” Adv. Healthcare Mater., Vol. 4, pp. 487-500, 2015

2) W. Honda, S. Harada, T. Arie, S. Akita, and K. Takei: "Wearable, Human-Interactive, Health-Monitoring, Wireless Devices Fabricated by Macroscale Printing Techniques," Adv. Funct. Mater., Vol. 24, pp. 3299-3304, 2014

3) S. Harada, T. Arie, S. Akita, and K. Takei: "Highly Stable LiquidSolid Metal Contact Toward Multilayered Detachable Flexible Devices,” Adv. Electronic Mater, Vol. 1, p. 1500080, 2015

4) S. Harada, W. Honda, T. Arie, S. Akita, and K. Takei: “Fully Printed, Highly Sensitive Multifunctional Artificial Electronic Whisker Arrays Integrated with Strain and Temperature Sensors," ACS Nano, Vol. 8, pp. 3921-3927, 2014

5) S. Harada, K. Kanao, Y. Yamamoto, T. Arie, S. Akita, and K. Takei: "Fully Printed Flexible Fingerprint-like Three-Axis Tactile and Slip Force and Temperature Sensors for Artificial Skin," ACS Nano, Vol. 8, pp. 12851-12857, 2014

6) K. Kanao, S. Harada, Y. Yamamoto, W. Honda, T. Arie, S. Akita, and K. Takei: "Highly Selective Flexible Tactile Strain and Temperature Sensors Against Substrate Bending for an Artificial Skin,” RSC Adv., Vol. 5, pp. 30170-30174, 2015

7) W. Honda, S. Harada, S. Ishida, T. Arie, S. Akita, and K. Takei: “High Performance, Mechanically Flexible, and Vertically Integrated Three-Dimensional Carbon Nanotube and InGaZnO Complementary Circuits with a Temperature Sensor," Adv. Mater., in press, 2015, DOI:10.1002/adma.201502116

8) M. Kaltenbrunner, T. Sekitani, J. Reeder, T. Yokota, K. Kuribara, T. Tokuhara, M. Drack, R. Schwodiauer, I. Graz, S. BauerGogonea, S. Bauer, and T. Someya: “An Ultra-Lightweight Design for Imperceptibl plastic Electronics," Nature, Vol. 499, pp. $458-463,2013$
9) D.-M. Sun, M. Y. Timmermans, A. Kaskela, A. G. Nasibulin, S. Kishimoto, T. Mizutani, E. I. Kauppinen, and Y. Ohno: “Mouldable All-Carbon Integrated Circuits," Nat. Commun., Vol. 4, p. 2302, 2013

10) K. Fukuda, Y. Takeda, Y. Yoshimura, R. Shiwaku, L. T. Tran, T. Sekine, M. Mizukami, D. Kumaki, and S. Tokito: "Fully-Printed High-Performace Organic Thin-Film Transistors and Circuitry on One-Micron-Thick Polymer Films," Nat. Commun., Vol. 5, p. 4147, 2014

11) C. Dagdeviren, Y. Shi, P. Joe, R. Ghaffari, G. Balooch, K. Usgaonkar, O. Gur, P. L. Tran, J. R. Crosby, M. Meyer, Y. Su, R. C. Webb, A. S. Tedesco, M. J. Slepian, Y. Huang, and J. A. Rogers: "Conformal Piezoelectric Systems for Clinical and Experimental Characterization of Soft Tissue Biomechanics," Nat. Mater., DOI:10.1038/nmat4289, 2015

12) M. Jung, J. Kim, J. Noh, N. Lim, C. Lim, G. Lee, J. Kim, H. Kang, K. Jung, A. D. Leonard, J. M. Tour, and G. Cho: “All-Printed and Roll-to-Roll-Printable 13.56-MHz-Operated 1-bit RF Tag on Plastic Foils," IEEE Trans. Electron Dev., Vol. 57, pp. 571-580, 2010

13) X. Wang, Y. Gu, Z. Xiong, Z. Cui, and T. Zhang: "Silk-Molded Flexible, Ultrasensitive, and Highly Stable Electronic Skin for Monitoring Human Physiological Signals," Adv. Mater., Vol. 26, pp. 1336-1342, 2014

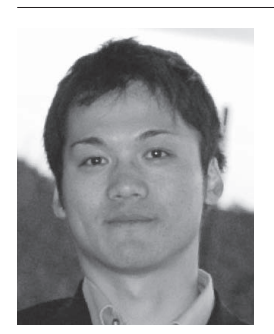

竹井邦晴（たけい くにはる）

著者紹介 2009 年豊橋技術科学大学大学院工学研究科電子・ 情報工学専攻博士課程修了, 博士 (工学)。同年 4 月よりカリフォルニア大学バークレー校博士研究 員（ローレンスバークレー国立研究所博士研究員 兼任) を経て，13 年より大阪府立大学大学院工学 研究科電子. 数物系専攻助教。1 13 年にMIT Technology Review 誌の 35 Top Innovators under 35 に選出。専門は電子デバイス, MEMS, ナノ材料 など。 